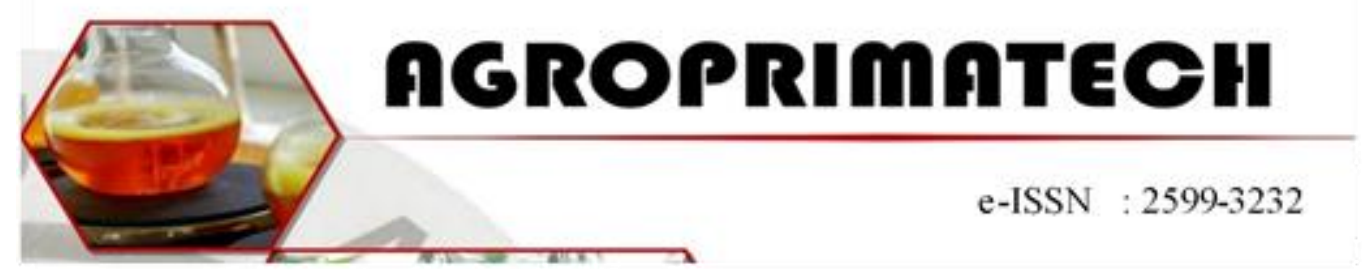

\title{
EFEKTIVITAS DAYA HAMBAT ASAP CAIR TEMPURUNG KELAPA (Cocus nucifera) TERHADAP PERTUMBUHAN JAMUR Ganoderma boninense
}

\author{
NUR ARIYANI AGUSTINA ${ }^{1}$ \\ ${ }^{1}$ Program Studi Agroteknologi, Universitas Prima Indonesia \\ Email:ninaagustina@gmail.com
}

\begin{abstract}
ABSTRAK
Asap cair mengandung berbagai senyawa yang dapat di kelompokkan ke dalam kelompok senyawa fenol, asam dan kelompok senyawa karbonil. Kelompok-kelompok senyawa tersebut berperanan sebagai anti mikroba, anti oksidan, pemberi flavor dan pembentuk warna. Karena asap cair dapat berperan sebagai anti mikroba dan anti oksigen, maka asap cair dapat digunakan sebagai bahan pengawet. Manfaat asap cair sebagai anti jamur dapat mengendalikan jamur Ganoderma boninense pada kelapa sawit pada busuk pangkal batang. Penelitian ini bertujuan untuk mengetahui manfaat asap cair tempurung kelapa dalam menghambat pertumbuhan jamur Ganoderma boninense. Hasil penelitian ini menunjukkan bahwa pada perlakuan yang paling efektivas menghambat pertumbuhan jamur paling rendah $\mathrm{C} 0$ dengan daya hambatnya $0 \%$ dan paling tinggi C4 dengan daya hambat $100 \%$. Hal ini menunjukkan bahwa asap cair tempurung kelapa memiliki manfaat dalam menghambat pertumbuhan jamur.
\end{abstract}

Kata Kunci : Asap Cair, Tempurung Kelapa, Jamur, Daya hambat.

\section{PENDAHULUAN}

Jamur, khususnya kelompok jamur makroskopis atau makrofungi (Basidiomycota), merupakan kelompok utama organisme pendegradasi lignoselulosa karena mampu menghasilkan enzim-enzim pendegradasi lignoselulosa seperti selulase, ligninase, dan hemiselulose (Munir. E 2006), sehingga siklus materi di alam dapat terus berlagsung. Selain itu, kelompok jamur makroskopis secara nyata mempengaruhi jarring jarring makanan di hutan, kelangsungan hidup atau perkecambahan anakan-anakan pohon, pertumbuhan pohon, dan keseluruhan kesehatan hutan. Jadi, keberadaan jamur makroskopis adalah indicator penting komunitas hutan yang dinamis (Molina, et all.2001)

Kerugian ekonomi yang di akibatkan oleh Ganoderma boninense terjadi di berbagai daerah di seluruh dunia termasuk Asia Tenggara (Corley dan Tinker, 2003). Menurut Idris et al., (2004) serangan penyakit busuk pangkal batang disebabkan fungi patogen Ganoderma boninense dalam pengembangan dan peningkatan produksi kelapa sawit di Asia Tenggara termasuk Indonesia terutama pada 
kebun peremajaan. Zakaria et al., (2005) melaporkan bahwa pada kebun peremajaan, kematian tanaman akibat busuk pangkal batang dapat mencapai $60 \%$. Ganoderma boninense tergolong fungi patogen tular tanah yang infeksi penyakit melalui perakaran dan penyebaran penyakit dengan cara menghasilkan basidiospora sebagai sumber inokulum infeksi penyakit busuk pangkal batang (Lee et all, 2005).

Pengendalian Ganoderma

boninense selama ini belum berhasil menekan perkembangan penyakit. Pengendalian dengan kultur teknis, mekanis, dan kimiawi sering mengalami kegagalan karena Ganoderma boninense merupakan patogen tular tanah dengan kemampuan saprofitik yang tinggi dan kisaran hospes tanamanyang luas (Nildayanti, 2011). Pengendalian Ganoderma boninense yang masih dilakukan menggunakan bahan kimia berupa fungisida menyebabkan residu, resistensi fungi patogen, pencemaran lingkungan biotik maupun abiotik dan tidak berhasil mengatasi penyebaran penyakit busuk pangkal batang. Penggunaan agens hayati dan nabati merupakan alternatif yang dapat dilakukan untuk mengendalikan penyakit busuk pangkal batang. Penekanan terhadap perkembangan penyakit busuk pangkal batang dilakukan dengan menggunakann agens hayati dan nabati melalui proses mekanisme antagonisme dan pengujian senyawa fitokimia. Pengujian senyawa fitokimia dilakukan dengan memanfaatkan hasil ekstraksi bahan alam berasal dari tumbuhan yang berpotensi menekan pertumbuhan fungi patogen.

Beberapa jenis jamur yang menyerang tanaman sawit salah satunya, jamur Ganoderma boninense merupakan penyakit yang paling merusak dalam perkebunan kelapa sawit di Indonesia khususnya di tanah gambut pengendalian dengan pestisida kimia memiliki dampak yang berbahaya untuk lingkungan dan kesehatan manusia. Pada kecambah dan bibit kelapa sawit Ganoderma boninense lebih cepat menyerang tanaman kelapa sawit dilahan gambut karena tunggultunggul kelapa sawit yang masih tersisa dalam tanah merupakan sumber infeksi yang paling kuat di kebun peremajaan (bekas kelapa sawit). Jamur Ganoderma boninense dapat menyerang kelapa sawit pada tahap produksi dan pembibitan. Gejala yang khas sebelum terbentuknya tubuh buah jamur, ditandai adanya pembusukan pada pangkal batang, sehingga menyebabkan busuk kering pada jaringan dalam (Semangun 2008). Pengendalian penyakit busuk pangkal batang diperlukan teknik yang tepat terutama pengendalian yang bersifat ramah lingkungan. Salah satu adalah pemanfataan asap cair (ASCI) tempurung kelapa.

\section{METODE PENELITIAN}

Penelitian ini dilakukan di Laboratorium Biomolekuler Fakultas Kedokteran Universitas Prima Indonesia dan dimulai pada bulan Juni 2019 sampai dengan selesai. Bahan yang digunakan dalam penelitian ini adalah asap cair tempurung kelapa komersil, jamur Ganoderma boninense dan alcohol 95\% alat yang digunakan dalam penelitian ini korek api, bunsen, petridish, spatula, inkubator, akuades, alat laminarair flowdan alat tulis.

\section{HASIL DAN PEMBAHASAN}

\section{Pengaruh Asap Cair Tempurung Kelapa Terhadap Pertumbuhan Jamur Ganoderma boninense \\ Berdasarkan hasil pengamatan jamur Ganoderma boninense menunjukkan kemampuan asap cair tempurung kelapa dalam menghambat}


Agroprimatech

Vol. 3 No. 2, April 2020

e-ISSN : 2599-3232

pertumbuhan jamur Ganoderma boninense yang dimana dapat diketahui secara statistik pemberian asap cair tempurung kelapa berpengaruh, dimana pada perlakuan $\mathrm{CO}$ berbeda nyata

dengan perlakuan $\mathrm{C} 1, \mathrm{C} 2, \mathrm{C} 3, \mathrm{C} 4$ tetapi perlakuan konsentrasi tidak berbeda nyata terhadap konsentrasi lainnya, hal ini dapat dilihat pada Tabel 1 dibawah ini :

Tabel 1 :Rataan diameter koloni jamur (cm) Ganoderma boninense terhadap pemberian asap cair tempurung kelapa

\begin{tabular}{ccc}
\hline Perlakuan & Rerata kloni jamur $(\mathrm{cm})$ & Daya hambat $(\%)$ \\
C0 & $1,93 \mathrm{a}$ & 0 \\
C1 & $1 \mathrm{~b}$ & 100 \\
C2 & $1 \mathrm{~b}$ & 100 \\
C3 & $1 \mathrm{~b}$ & 100 \\
C4 & $1 \mathrm{~b}$ & 100 \\
\hline
\end{tabular}

Berdasarkan pada Tabel 1 diatas rerataan diameter daya tumbuh jamur Ganoderma boninense tertinggi terdapat pada perlakuan kontrol ataupun CO yaitu $1,93 \mathrm{~cm}$ hal ini di karenakan perlakuan $\mathrm{C} 0$ menggunakan PDA $10 \mathrm{ml}+0 \mathrm{ml}$ asap cair dengan konsentrasi $0 \%$ atau tanpa asap cair. Sedangkan pada daya hambat tumbuh jamur Ganoderma boninense pada perlakuan $\mathrm{C} 1$ sampai dengan $\mathrm{C} 4$ dengan konsentrasi asap cair tertentu sudah menunjukkan asap cair dengan signifikan menghambat pertumbuhan jamur Ganoderma boninense, dengan perlakuan terkecil $\mathrm{C} 1$ yaitu $1 \mathrm{~cm}$ hal ini dikarenakan perlakuan asap cair $0,5 \mathrm{ml}$ + PDA 9,5 ml konsentrasi 5\% adalah sesuai untuk menghambat daya pertumbuhan jamur Ganoderma boninense dan pada perlakuan tertinggi C4 $1 \mathrm{~cm}$ dengan perlakuan asap cair 2 $\mathrm{ml}+$ PDA $8 \mathrm{ml}$ konsentrasi $20 \%$ menunjukkan hasil yang sama terhadap daya pertumbuhan jamur Ganoderma boninense dengan perlakuan terkecil.
Hal ini sesuai dalam pernyataan Priyamto (2012) asap cair tempurung kelapa mengandung senyawa fenol yang mampu menghambat pertumbuhan bakteri atau jamur sehingga dapat digunakan sebagai disinfektan. Daya racun fungisida yang berperan dalam menghambat pertumbuhan jamur didalam asap cair berasal dari komponen fenol dan asam. Pertumbuhan Ganoderma boninense relative lambat pada media PDA dimana untuk masa pertumbuhannya sendiri membutuhkan 1-7 hari untuk tumbuh memenuhi cawan petridish dan pertumbuhan jamur juga bisa dipengaruh dengan struktur jamur atau juga daya tumbuh jamur yang dimana menurut (Aeny, 2010). Trichoderma spp.mempunyai kecepatan pertumbuhan pertumbuhan koloni paling cepat, hanya membutuhkan waktu 7-9 hari dibandingkan pertumbuhan Ganoderma boninense yang membutuhkan waktu 15-40 hari. Jadi dengan hasil pegamatan yang dilakukan secara visual atau juga 
secara langsung efeketivitas daya hambat asap cair dalam penghambatan pertumbuhan jamur Ganoderma boninense berpengaruh pada perlakuan konsentrasi C1 sampai C4 dengan menggunakan dosis tertentu pertumbuhan jamur Ganoderma boninense dapat di tekan oleh asap cair tidak harus dengan menggunakan dosis yang banyak, hal ini dapat dilihat dari penelitian ini yang dimana pada cawan petridish yang menggunakan asap cair tempurung kelapa tidak adanya perubahan ataupun menunjukakan adanya pembentukkan miselium pada media PDA yang sudah tercampur dengan asap cair tempurung kelapa, maka konsentrasiyang digunakan efektif dalam menekan pertumbuhan jamur dan juga pertumbuhan jamur Ganoderma yang tergolong lama dalam masa perkembangan juga sebagai pengaruh jamur tersebut lambat tumbuh dan membuat senyawa aktif yang terkandung dalam asap cair lebih efektif.

\section{Pengaruh Asap Cair Tempurung Kelapa Terhadap Diameter Jamur Ganoderma boninense}

Berdasarkan pada Tabel 1 hasil pengamatan visual dilakukan selama 14 hari terhadap pertumbuhan diameter jamur Ganoderma boninense perlakuan kontrol $\mathrm{C} 0$ asap cair $0 \mathrm{ml}+$ PDA $10 \mathrm{ml}$ hasilnya miselium tumbuh pada cawan petridish dengan rataan diameter koloni jamur 1,93 cm sedangkan hasil pengamatan pada perlakuan ter-rendah sampai tertinggi dimana $\mathrm{C} 1$ dengan pemberian asap cair 0,5 ml PDA 9,5 ml dan C4 dengan pemberian asap cair 2 $\mathrm{ml}+$ PDA $8 \mathrm{ml}$ hasil tumbuh diameter koloni jamur menunjukkan sama tidak mengalami perubahan tetap seperti diameter awal jamur yaitu $1 \mathrm{~cm}$ atau tidak ada munnculnya pertumbuhan miselium pada beberapa cawan petridish dengan taraf konsentrasi 5\% dan $20 \%$ jamur Ganoderma boninense mengalami

pertumbuhan, hal tersebut menunjukkan bahwa jamur Ganoederma boninense terhambat pertumbuhannya sehingga kecepatan pertumbuhan diameter jamur lebih lambat. Fungisida dapat bersifat fungistatik, yaitu bersifat tidak membunuh cendawan tetapi hanya menghambat pertumbuhan serta bersifat genestatik yang mencegah sporulasi. Ini terjadi karena aktifitas antimikrobia asap cair tempurung kelapa yang dimana disebabkan oleh kandungan senyawa antimikrobia yang terkandung dalam asap cair tersebut dikelompokkan dalam fenol dan asam, pada proses penghambatan pertumbuhan jamur dipengaruhi oleh senyawa yang bersifat antimikroba pada asap cair tempurung kelapa yaitu: fenol Phenol, 2-ethylphenol, 3Methylphenol, 2,6-Dimethylphenol, 2,4Dimethylphenol, dan 3-hylphenol serta senyawa asam 2,3dihydroxy-benzoic acid, 3-methoxybenzoic acid methyl ester, dan 4-Hydroxy-benzoic acid methyl ester (Karseno et al 2002) dimana jauh lebih tinggi dan berbeda nyata bila dibandingkan dengan perlakuan yang menggunakan asap cair tempurung kelapa, Seperti yang dinyatakan oleh Darmadji (1996), bahwa dibanding dengan asap cair dari jenis kayu lainnya, asap cair tempurung kelapa mempunyai kelebihan dalam menghambat pertumbuhan mikroorganisme dan patogen. Sejauh penelitian ini dilakukan selain asap cair yang mengandung anti jamur ada juga faktor lain yang dapat menghambat diameter tumbuh jamur tersebut yang dimana faktor lain itu bisa disebabkan dengan pertumbuhan jamur yang lambat dan bisa juga disebabkan dengan struktur jamur lebih padat dimana dalam pertumbuhan bisa memperlambat ataupun dapat 
Agroprimatech

Vol. 3 No. 2, April 2020

e-ISSN : 2599-3232

menghambat pertumbuhan jamur Ganoderma boninense, dalam pernyataan (Aeny, 2010). Trichoderma spp. mempunyai kecepatan pertumbuhan pertumbuhan koloni paling cepat, hanya membutuhkan waktu 7-9 hari dibandingkan pertumbuhan Ganoderma boninense yang membutuhkan waktu 15-40 hari.

\section{Daya hambat asap cair terhadap pertumbuhan pertumbuhan jamur}

Berdasarkan penelitian yang sudah dilakukan pada hasil pengujian menunjukkan bahwa asap cair memiliki aktivitas antimikrobia asap cair

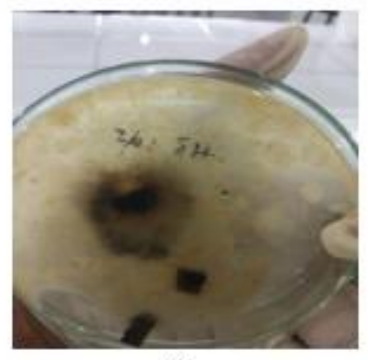

A

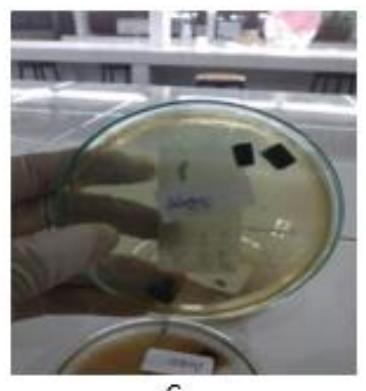

C tempurung kelapa disebabkan oleh kandungan senyawa antimikrobia yang terkandung dalam asap cair tersebut yaitu dikelompokkan dalam fenol dan asam yang dapat menekan pertumbuhan jamur Ganoderma boninense. Menurut Priyamto (2012) asap cair tempurung kelapa mengandung senyawa fenol yang mampu menghambat pertumbuhan bakteri atau jamur sehingga dapat digunakan sebagai disinfektan, berikut disajikan gambar Efektivitas Daya Hambat Asap Cair Tempurung Kelapa Terhadap Pertumbuhan Jamur Ganoderma boninense:

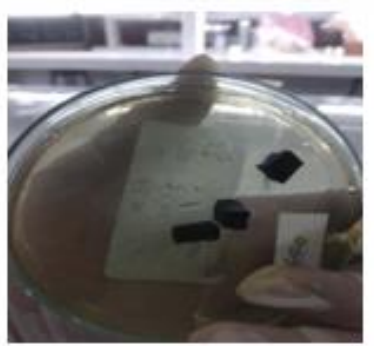

B

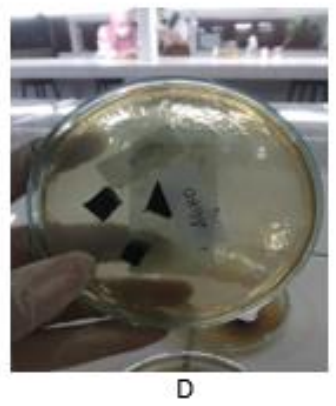

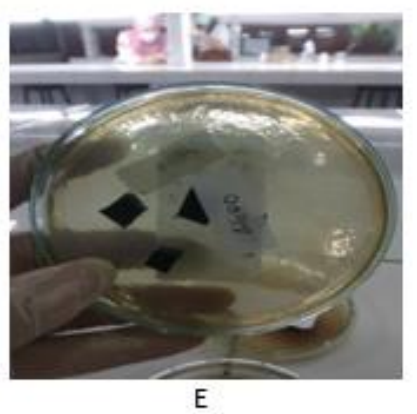

Gambar 1. Efektivitas daya hambat ASCI tempurung kelapa terhadap pertumbuhan jamur Ganoderma boninense 
Agroprimatech

Vol. 3 No. 2, April 2020

Pada gambar diatas tersebut bisa diketahui dimana pada gambar $\mathrm{A}$ atau pada perlakuan kontrol $\mathrm{C} 0$ tidak mempengaruhi daya hambat pertumbuhan jamur tersebut sedangkan pada gambar B sampai $E$ daya hambat asap cair tempurung kelapa terhadap jamur Ganoderma boninense menunjukkan angka 100\% berarti yang dimana pada pemberian asap cair untuk menghambat daya tumbuh jamur Ganoderma boninense berpengaruh berbeda nyata dan pemberian asap cair tempurung kelapa untuk menekan pertumbuhan jamur Ganoderma boninense efektif karena pada asap cair tempurung kelapa menangdung senyawa-senyawa aktif yang bisa memperlambat atau juga menghambat pertumbuhan jamur.

Kombinasi antara komponen fungsional fenol dan asam-asam organik yang bekerja secara sinergis mencegah dan mengontrol pertumbuhan mikrobia (Pszczola dalam Astuti, 2000). Adanya fenol dengan titik didih tinggi dalam asap juga merupakan zat antibakteri yang tinggi (Astuti, 2000). Hal ini di buktikan pada gambar yang sudah di sajikan diatas dimana pada gambar A miselium tumbuh di media PDA dan sedangkan pada gambar $\mathrm{B}, \mathrm{C}$, $D$, dan $E$ tidak menunjukkan adanya pertumbuhan miselium di petridish yang sudah diberikan media PDA.

\section{Kesimpulan}

ASCI memiliki kandungan anti jamur yang bermanfaat dan efektif dalam manghambat pertumbuhan jamur terlihat pada perlakuaan C4 yaitu 100\% dan dengan diameter $1 \mathrm{~cm}$ sedangkan pada perlakuaan $\mathrm{C} 0$ memiliki daya hambat $0 \%$ dengan diameter $1,93 \mathrm{~cm}$, sehingga $\mathrm{ASCl}$ dapat dimanfaatkan untuk pengendalian pertumbuhan jamur.

$$
e-I S S N \quad: 2599-3232
$$

\section{DAFTAR PUSTAKA}

Abadi AL, Dharmaputra OS. 1998. Pengaruh $\mathrm{pH}$ medium dan suhu terhadap pertumbuhan miselium Ganoderma boninense. Laporan tahunan kerjasama penelitian Pusat Penelitian Marihat-Biotrop tahun 1998.

Aeny TN. 2010. Pengaruh beberapa isolat Trichoderma spp. pada pertumbuhan in vitro Ganoderma boninense, penyebab penyakit busuk pangkal batang pada kelapa sawit (Elaeis guineensis). Di dalam: Pengelolaan keragaman hayati tanah untuk menunjang keberlanjutan produksi pertanian tropika. Prosiding Seminar Nasional Keragaman Hayati Tanah-l; Bandar Lampung, 29-30 Juni 2010. Universitas Lampung. hlm. 304-316.

Agrios, G.N. 1996. Ilmu Penyakit Tumbuhan, Gajah Mada University Press, Yogyakarta.

Alexopoulos, C.J., Mims, C.W \& Blackwell, $\quad M$. 1996. Introductory Mycologi. John Wiley \& Sons, Singapore. p. 244 - 324.

Astuti, 2000. Aplikasi Asap Cair Sebagai Solusi Dalam Peningkatan Mutu Dan Kualitas Benih. Prosiding Seminar Nasional Pangan. Institut Pertanian Bogor.

Badan Pusat Statistik. 2008. Statistik Sentra Daerah Kelapa Indonesia. Lampung: CV. Sukorejo Bersinar 
Agroprimatech

Vol. 3 No. 2, April 2020

Bakar, E. S. 2003. Kayu Sawit Sebagai Subtitusi Kayu Dari Hutan Alam. Forum Komunikasi dan Teknologi dan Industri kayu 2 : 5-6. Bogor

Baker, R. and Scher F. M. 1987. Enhancing the activity of biological control angents, In Innovative Approaches to Plant Disease Control. Chet. JhonWiley dan Sons. New York 1: 1-17

Corley, R. H. V., and Tinker, P. B., 2003, The Oil Palm. 4th Edition. Blackwell Science Ltd. Iowa, USA

Darmadji, P. (1996). Aktivitas antibakteri asap cair yang diproduksi dari bermacam-macam limbah pertanian. Agritech 16 (4): 1922.

Darmadji, P., K.R. Wulandari, dan U. Santoso. 1999. Sifat Antioksidatis Asap Cair Hasil Redistilasi Selama Penyimpanan. Prosiding Seminar Nasional Pangan.Pusat Antar Universitas Pangan dan Gizi UGM.Yoyakarta.

Direktorat Jenderal Perkebunan. 2012. Karet dan Kelapa Sawit Masih Menjadi

AndalandevisaSubsektorPerke bunan.http://ditjenbun.deptan. go.id/index.php/component/co ntent/article/36-news/265karet-dan-kelapa-sawit-masihmenjadi-andalan-devisasubsektor-perkebunan.html.

Fenty, F, 2012, Kajian busuk buah pada Kelapa Sawit di Kabupaten
e-ISSN : 2599-3232

Aceh Timur. Balai Teknisi Pertanian. Banda Aceh.

Girard. 1992. "Smoking in : Technology of Meat Product". Translated by Bernard Hammings and ATT. Clermont Ferrand. Ellis Horwood, New York. 165-205.

Hjeljord, L. and A. Tronsmo, 1998. Trichoderma and Gliocladium in biological control: an overview. Pp. 131-152. In: G.E. Harman and C.P. Kubicek (Eds.), Trichoderma and Gliocladium Vol. 2. Taylor \& Francis Ltd., London

Hood, I. A. 2006. The Mycology of the Basidiomycetes. ACIAR Proceedings

Idris AS, Kushairi S, Ismail S, Arifin D. 2004. Selection for partial resistance in oil palm progenies to Ganoderma basal stem rot. J Oil Palm Res 16:1218

Indrawati Gandjar,1999, Pengenalan Kapang Tropik Umum, Jakarta: Yayasan

Obor Indonesia.

Karseno, 2002. Daya hambat asap cair kayu karet terhadap bakteri pengkontaminasi lateks dan ribet smoke sheet. Agritech, 21, 1: 10-15

Lee CS, Lee YJ, Jeun YC. 2005. Observations of infection structures on the leaves of cucumber plants pre-treated with arbuscular mycorrhiza Glomus intraradices after challenge inoculation with Colletotrichum orbiculare. Plant Pathol J 21 :237- 243. 
Maga, J.A. 1987, Smoke in Food Processing, CRC Press, Inc., Boca Raton, Florida.

Mangoensoekarjo, S. dan A. T. Tojib. 2005. Manajemen Budidaya Kelapa Sawit. Hal 1-318 Dalam S. Mangoensoekarjo dan $\mathrm{H}$ Semangun (Eds.) Manajemen Agrobisnis Kelapa Sawit. Gajah mada University Press. Yogyakarta.

Miller, R.N.G., M. Holderness, and P.D. Bridge. 2000. Molecular and morphological characterization of Ganoderma in oil-palm planting. In: Flood J, Bridge PD, Holderness M (eds). Ganoderma Diseases of Perenial Crops. CABI Publishing, Wallingford, UK. Pp. 159-182

Molina, R., D. Pilz, J. Smith, S. Dunham, T. Dreisbach, T. O'Dell, dan M. Castellano. 2001. Conservation and Management of Forest Fungi in The Pacific Northwestern United States: An Integrated Approach. Cambridge University Press. Cambridge

Munir, E. 2006. Pemanfaatan Mikroba dalam Bioremediasi: Suatu Teknologi Alternatif untuk Pelestarian Lingkungan. Pidato Pengukuhan Jabatan Guru Besar Tetap dalam Bidang Mikrobiologi FMIPA USU. USU Repository. Medan.

Nildayanti, 2011. Peran Bakteri Kitinolitik Dan Fungi Mikoriza Arbuskular dalam Pengendalian Busuk Pangkal Batang Kelapa Sawit. (Tesis). Bogor: Sekolah Pasca Sarjana, Institut Pertanian Bogor.
Oka, I N. 1979. Cultural control of the brown planthopper. Brown Planthopper: Threat To Rice Production in Asia : 357-369.

Pranata, J. 2007. Pemanfaatan sabut dan tempurung kelapa serta cangkang sawit untuk pembuatan asap cair sebagai pengawet makanan alami. (Skripsi).

Teknik Kimia Universitas Malikussaleh. Lhoksumawe.

Pszczola, D.E. (1995). Tour highlights production and uses of smokebased $\mathrm{fl}$ avors. Food Technology 49 (1): 70-74.

Priyamto S, H.A. 2012. Aplikasi Asap Cair Dari Kayu Leban (Vitex pubescens Vahl) Untuk Pengendalian Jamur Pada Benih Tusam (Pinus merkusii Jungh et de vriese) Secara In Vitro. Jurnal Hutan Lestari.

Ratnaningtyas, 2007. Karakter Ganoderma spp. Di Kabupaten Banyumas serta Uji Peran Basidiospora dalam Siklus Penyakit Busuk Batang. Universitas Jendral Soedirman, Purwokerto.

Robinson, R. 2001. Biology Macmillan Science Library. Macmillan Reference, USA.

Ruiter, A. 1979. Color of Smoked Foods. Fodda Technol. 33 (5) : 54-63.

Semangun, H. 2000. Penyakit-Penyakit Tanaman Perkebunan di Indonesia (Revisi). Gadjah Mada University Press: Yogyakarta. 808 Hal. 
Agroprimatech

Vol. 3 No. 2, April 2020

Semangun, H. 2008. Penyakit-Penyakit Tanaman Pangan Di Indonesia.Edisi kedua. Gadjah Mada University Press, Yogyakarta.

Sastrosayono, S. 2008. Budidaya Kelapa Sawit. Agromedia Pustaka. Jakarta.

Semangun, H. 1975. Fitopatologi dan Konsep "Pest

Management". Kongres

Nasional PFI III. Bogor.

Semangun, H. 2001.Pengantar IImu Penyakit Tumbuhan. Gadjah Mada University Press, Yogyakarta.

Sink dan Hsu, 1997. Leaf senescence in plants: from model plants to crops, still so many unknowns. J. of Integrative Plant Biology 54 (8): 514-515. DOI: $10.1111 /$ j.1744-7909.2012.01148.x

Sinaga, M.S, 1990, Jamur Merang dan Budidayanya, Jakarta: Penebar Swadaya

. Tranggono, Suhardi, Setiadji B, Darmadji P, Supranto, \& Sudarmanto. 2000. Identifikasi Asap Cair dari Berbagai Jenis Kayu dan Tempurung Kelapa, J.Ilmu dan Teknologi Pangan.

Siregar, H. H., Harahap. I. Y., Darmosarkoro. W dan Sutarta. E. 2005. Kekeringan pada kelapa sawit.Seri buku saku 10.PPKS. Medan.

Sunarko. 2009. Budidaya dan Pengelolaan Kebun Kelapa Sawit dengan Sistem Kemitraan.
e-ISSN :2599-3232

Jakarta (ID): Agromedia Pustaka. 178 hlm.

Triharso. 1978. Beberapa Gatra Pengendalian Penyakit Tumbuhan dan Kemungkinan Penerapannya di Indonesia, Pidato Pengukuhan Jabatan Guru Besar pada Fakultas Pertanian UGM, 25 Nopember 1978. $33 \mathrm{p}$.

Tranggono, Suhardi dan Setiadji, B, 1997 Produksi asap cair dan penggunaanya pada pengolahan beberapa bahan makanan khas Indonesia, Laporan akhir riset unggulan terpadu III. Kantor Menteri Negara Riset dan Teknologi, Proyek Puspiptek.

Ward, M. 2004. Beberapa spesies Ganoderma memproduksi enzim-enzim, London.

Warisno. 2003. Budidaya Kelapa. Yogyakarta: Kanisius

Widyastuti, S. M.., Sumardi, dan N. Hidayati. 1998a. Kemampuan Trichoderma spp. Untuk Pengendalian Hayati Jamur Akar Putih pada Acacia mangium secara In vitro. Bul.Kehut. 36: 11-13

Zakaria L, Singham HK, Guan TS, Abdullah F, Wan HY. 2005. Random amplified polymorphic DNA (RAPD) and random amplified microsatelit (RAMS) of Ganoderma from infected oil palm and coconut stumps in Malaysia. Asia Pacific J Mole Biol Biotechnol 13: 23-34 